\title{
Contents, Vol. 20, 1970
}

Editors Editorial Board

M. Hauge, Kßbenhavn A. C. Allison, London

L. Beckman, Umeå A. G. Bearn, New York, N.Y.

K. Berg, Oslo

L. van Bogaert, Antwerpen J. A. Book, Uppsala L. L. Cavalli-Sforza, Parma

E. Essen-Möller, Lund

J. Francois, Gent

F. C. Fraser, Montreal

J. A. Fraser Roberts, London

N. Freire-Maia, Curitiba

J. Frézal, Paris

L. Gedda, Rome

R. Grubb, Lund

K. Henningsen, København

D. Klein, Geneve

T. Larsson, Stockholm

H. Lehmann, Cambridge

J. Mohr, København

A. E. Mourant, London

H. Nachtsheim, Berlin

J. V. Neel, Ann Arbor, Mich.

P. O. Pedersen, København

S. Refsum, Oslo

L. D. Sanghvi, Bombay

M. Siniscalco, Leiden

T. Sjögren, Göteborg

E. T. 0. Slater, London

A. C. Stevenson, Oxford

E. Strömgren, Åarhus

R. Turpin, Paris

F. Vogel, Heidelberg

S. Karger AG, Arnold-Böcklin-Strasse 25, CH-4000 Basel 11 (Switzerland)

All rights, including that of translation into other languages, reserved. Photomechanic reproduction (photocopy, microcopy) of this volume or parts thereof without special permission of the publishers is prohibited.

(C) Copyright 1970 by S. Karger AG, Verlag für Medizin und Naturwissenschaften,

Basel

Printed in Switzerland by Lüdin AG, Liestal

Index

Abe, K.; Amatomi, M., and Kajiyama, S.: Genetical and Developmental

Aspects of Susceptibility to Motion Sickness and Frost-bite . . 507

Afeltra, P.: vide Modiano, G.

Amatomi, M.: vide Abe, K.

Angelopoulos, B. T. and Delitheos, A. K.: Glucose-6-Phosphate De-

hydrogenase Variants in Greeks

66

Arce-Gomez, B.; Azevedo, J. B. C.; Chautard, Eleidi A., and Freire-

Maia, N.: A Genetic Study on Palatolabial Defects 580 
Ashbel, S.: vide Bonne, B.

Azevedo, J. B. C.: vide Arce-Gomez, B.

Azevedo, J. B. C.: vide Freire-Maia, N.

Azevedo-Fialho, Maria da Graça M. de: vide Freire-Maia, N.

Azzarone, G.: vide Scozzari, R.

Bajatzadeh, M.: vide Pálsson, J. O. P.

Ba, iatzadeh, M.: vide Walter, $\mathrm{H}$.

Baxi, A. J.: vide Blake, N. M.

Beckman, G.: Placental Alkaline Phosphatase, Relation between Phenotype and Enzyme Activity $\quad 74$

Beckman, G. and Beckman, L.: Relation between the ABO Blood Groups and the Level of Placental Alkaline Phosphatase in Sera of

Pregnant Women 187

Beckman, G.; Beckman, L., and Lundgren, E.: Isozyme Variations in Human Cells Grown in vitro. IV. Identity between Alkaline Phosphatases from HeLa Cells and Placenta? 182

Beckman, G.; Beckman, L., and Tärnvik, A.: A Rare Subunit Variant Shared by Five Acid Phosphatase Isozymes from Human Leuko cytes and Placentae 81

Beckman, G.: vide Beckman, L.

Beckman, L.; Beckman, G., and Stigbrand, T.: Relation Between the Pregnancy Zone Protein and Fetal Sex 530

Beckman, L.; Olivecbona, T., and Hernell, 0.: Serum Lipids and Their Relation to Blood Groups and Serum Alkaline Phosphatase Isozymes 569

Beckman, L.: vide Beckman, G.

Beiguelman, B.; Colli-Inglez, Glaucia; Bonder-Itskan Suely, and

Saldanha, P. H.: Glucose-6-phosphate Dehydrogenase Activity

Among Caucasoid Twins 535

Berger, J.: vide Weitkamp, L. R.

Bhasin, M. K.: Group Differences Among Newars of Nepal for Palmar Interdigital Areas 604

Blake, N. M.; Kirk, R. L., and Baxi, A. J.: The Distribution of Some

Enzyme Group Systems Among Marathis and Gujaratis in

Bombay 409

Bonder-Itskan, Suely: vide Beiguelman, B.

Bonne, B.; Ashbel, S.; Modai, M.; Godber, M. J.; Mourant, A. E.; Tills, D., and Woodhead, B. G.: The Habbanite Isolate. I. Genetic

Markers in the Blood 609

IV

Index

Braend, M.: vide Weitkamp, L. R.

Branden, J. L. Van den: vide Tills, D.

Brown, K. S. and Johnson, R. S.: Population Studies on Southwestern

Indian Tribes. III. Serum Protein Variations of Zuni and Papago

Indians 281

BwiBO, N. O. and Mkono, M. D.: Waardenburg's Syndrome in an African Child $\quad 19$

Chattopadhyay, P. K.: Frequency of Colour Blindness Among the Jats .

Chattopadhyay, P. K.: Palmar Dermatoglyphics of the Gujars

Chautard, Eleidi A.: vide Arce-Gomez, B.

Christodoulou, C.: vide Pataryas, H. A.

Clements, V. R.: vide Tills, D.

Cleve, H.: The Group-Specific Component (Gc) in Chimpanzees

Golli-Inglez, Glaucia: vide Beiguelman, B.

Dar, H. and Winter, S. T.: A Study of Dermatoglyphics and the Simian

Crease in Familial Deafness 493

Das, S. K.: vide Mukherjee, B. N. 
Delitheos, A. K.: vide Angelopoulos, B. T.

Dissing, J. and Knudsen, J. B.: Human Erythrocyte Adenosine Deaminase Polymorphism in Denmark 178

Dodinval, P. A.: Population Structure of A, B, 0, AB Blood Groups in Belgium $\quad 169$

Drachmann, 0.: vide Weitkamp, L. R.

Eriksson, A. W.; Fellman, J.; Forsius, H., and Lehmann, W.: Phenylthiocarbamide Tasting Ability among Lapps and Finns 623

Eriksson, S. A.: vide Herrlin, K.-M.

Evrev, T.; Zhivcov, S., and Russev, L.: LDH Isoenzymes in Testicular Cultures and Human Testes 70

Fellman, J.: vide Eriksson, A. W.

Forsius, H.: vide Eriksson, A. W.

Franglen, G.: vide Weitkamp, L. R.

Fraser, F. C.: vide Preus, M.

Frattaroli, W.: vide Modiano, G.

Freiden, F. J.: vide Krush, Anne J.

Freire-Maia, Flávia L. N.: vide Freire-Maia, N.

Freire-Maia, N. and Azevedo, J. B. C.: Inbreeding and Celibacy .... 383

Freire-Maia, N.; Azevedo-Fialho, Maria da Graça M. de, and Freire-

Maia, Flávia L. N.: Inbreeding Load, as Estimated with Sib

Control, in a Portuguese Population 248

Freire-Maia, N.: vide Arce-Gomez, B.

Gigliani, F.: vide Modiano, G.

Gigliani, F.: vide Terrenato, L.

Godber, M. J.: vide Bonne, B.

Götestam, K. G.: vide Holmgren, G.

Guttman, Ruth : Parent-Offspring Correlations in the Judgment of Visual Number 57

Hamlett, J. D.; Timson, J., and Harris, R.: XX/XXY Mosaicism in a

Phenotypically Normal Female 260

Harris, R.: vide Hamlett, J. D.

Hauge, M.; Heiken, A., and Höglund, C.: Studies on the Haptoglobin

System. II. The Development and Distribution of Hp Groups in

Children 557

Index $\mathrm{V}$

Hauge, M.: vide Herrlin, K.-M.

Hauge, M.: vide Höglund, C.

Heiken, A.: vide Hauge, $M$.

Heiken, A.: vide Höglund, C.

Henningsen, K.: vide Lamm, L. U.

Hernell, O.: vide Beckman, L.

Herrlin, K.-M.; Hauge, M., and Eriksson, S. A.: Finger Print Patterns in an Unselected Series of Triplets

Hníková, 0.: vide Subrt, I.

Höglund,C; Heiken, A., and Hauge, M.: Studies on the Haptoglobin System. I. The Distribution of Hp Groups in the Swedish Popula tion 549

Höglund, C.: vide Hauge, M.

Holmgren, G. and Götestam, K. G.: Haptoglobin and Transferrin Variants in Two Congolese Bantu Tribes

Horváth, L.: vide Schuler, D.

Ishimoto, G.: Distribution of Placental Alkaline Phosphatase Types in a Japanese Population 193

Jakobsson, A.: vide Skude, G.

James, W. H.: Curve Fitting, Maternal Age and Mongolism 417

Jantz, R. L.; Johnston, F. E.; Kensinger, K. M., and Walker, G. F.:

Palmar Dermatoglyphics of the Peruvian Cashinahua 
Johnson, R. S.: vide Brown, K. S.

Johnston, F. E.: vide Jantz, R. L.

Joó-Szabados, Teréz: The Frequency of Fya and Fyb Antigens in the

Population of Budapest

436

Kajiyama, S.: vide Abe, K.

Kattamis, C. and Lehmann, H.: The Genetical Interpretation of Haemo

globin H Disease 156

Kensinger, K. M.: vide Jantz, R. L.

Kimura, T.: vide Neel, J. V.

Kirk, R. L.: vide Blake, N. M.

Kissmeyer-Nielsen, F.: vide Lamm, L. U.

Knudsen, J. B.: vide Dissing, J.

Koós, R.: vide Schuler, D.

Krush,Anne J.; Sharp, E.A.;Lynch, H.T., andFreiden,F. J.: AComputer

Based System of Coding for Genetic Studies of Large Kindreds 447

Lamm, L. U.: Family, Population and Mother-Child Studies of Two Phospho-

glucomutase Loci (PGMX and PGM3). Lack of Close Linkage

between the Two Loci $(\omega>0.33) \quad 292$

Lamm, L. U.: Family Studies of Red Cell Acid Phosphatase Types. Report of

a Family with the D Variant 329

Lamm, L. U.; Kissmeyer-Nielsen, F., and Henningsen, K.: Linkage and

Association Studies of Two Phosphoglucomutase Loci (PGMj and

PGM3) to Eighteen Other Markers. Analysis of the Segregation at

the Marker Loci 305

Larson, C. A. and Nyman, G. E.: Age of Onset in Schizophrenia

Lauridsen, U. Birk: vide Ropartz, C.

Lehmann, H.: vide Kattamis, C.

Lehmann, W.: vide Eriksson, A. W.

Levy, E. P.: vide Preus, M.

VI

Index

Lie-Injo, L. E. and Poey-Oey, H. G.: Phosphoglucomutase, Carbonic

Anhydrase and Catalase in Indonesians 215

Lundgren, E.: vide Beckman, G.

Lynch, H. T.: vide Krush, Anne J.

Masters on, J. G.: Consanguinity in Ireland 371

Mayo, O.: On the Effects of Genetic Counselling on Gene Frequencies . . 361

Mayo, O.: The Use of Linkage in Genetic Counselling

473

Mayr, W. R.: Studies on the Correlation between the Secretor System and

the Gc Serum System 287

Mikkelsen, Margareta and Stene, J.: Genetic Counselling in Down's

Syndrome 457

Mkono, M. D.: vide Bwibo, N. 0.

Modai, M.: vide Bonne, B.

Modiano, G.; Scozzari, R.; Gigliani, F.; Santolamazza, C.; Afeltra, P., and Frattaroli, W.: Red Cell Phosphoglucomutase Poly

morphism. I. Enzyme Activity of Different Red Cell PGM Pheno-

types $\quad 86$

Modiano, G.: vide Terrenato, L.

Mourant, A. E.: vide Bonne, B.

Mourant, A. E.: vide Tills, D.

Mukherjee, B. N. and Das, S. K.: The Haptoglobin and Transferrin Types

in West Bengal and a Case of Haptoglobin 'Johnson'

Nakajima, A.: vide Neel, J. V.

Natvig, J. B.: vide Nielsen, J. C.

Neel, J. V.; Schull, W. J.; Kimura, T.; Tanigawa,Y.; Yamamoto, M.,

and Nakajima, A.: The Effects of Parental Consanguinity and

Inbreeding in Hirado, Japan. III. Vision and Hearing 129 
Nemeskéri, J.: vide Walter, H.

Nielsen, J. C.: Four Families Demonstrating a Rare Aberrant Reaction of anAnti-Gm(a) 220

Nielsen, J. C. and Natvig, J. B.: The Rare Phenotype Gm(a-z-x+) in

3 Danish Families 265

Nyman, G. E.: vide Larson, C. A.

Olivecrona, T.: vide Beckman, L.

Pal, A.: Ear Lobe Attachment of the Onge 650

Pálsson, J. 0. P.; Walter, H., and Bajatzadeh, M: Sero-Genetical Studies in Ireland 231

Pataryas, H. A. and Christodoulou, C.: Leucine Aminopeptidase Vari ations in Human Foetal Organs 325

Pataryas, H. A. and Christodoulou, C.: Alterations in Human Organ

Alkaline Phosphatases During Foetal Development 420

Persson, I.: vide Ropartz, C.

Poey-Oey, H. G.: vide Lie-Injo, L. E.

Preus, M.; Fraser, F. C, and Levy, E. P.: Dermatoglyphics in Congenital Heart Malformations 388

Rao, D. C.: Tongue Pigmentation in Man 8

Rao, D. C.: A Contribution to the Genetics of Hypertrichosis of the Ear Rims 486

Rao, D. C.: Genetics of Tongue Pigmentation in Man 590

Rao, D. C: The Relation Between Tongue Pigmentation and Mental

Ability $\quad 6() 0$

Renwick, J. H.: vide Weitkamp, L. R.

Index VII

Rivat, L.: vide Ropartz, C.

Ropartz, C; Rivat, L.; Rousseau, P. Y.; Lauridsen, U. Birk, and

Persson, I.: A Survey of $9 \mathrm{Gm}$-Factors, the Inv and the ISf

Systems in Danes 275

Rousseau, P. Y.: vide Ropartz, C.

Russev, L.: vide Evrev, T.

Saldanha, P. H.: vide Beiguelman, B.

Santolamazza, C.: vide Modiano, G.

Santolamazza, C.: vide Scozzari, R.

Santolamazza, C.: vide Terrenato, L.

Schuler, D.; Koós, R.; Siegler, J., and Horváth, L.: Thyroid Autoanti-

bodies and Satellite Associations in Down's Syndrome

Schull, W. J.: vide Neel, J. V.

Scozzari, R.; Santolamazza, C.; Spennati, G. F., and Azzarone, G.: Red

Cell Acid Phosphatase, Phosphoglucomutase and Adenylatekinase

Polymorphisms in the District of L'Aquila (Italy) 104

Scozzari, R.: vide Modiano, G.

Scozzari, R.: vide Terrenato, L.

Selvin, S.: Twin Zygosity Diagnosis by Blood Group Antigens

Sharp, E. A.: vide Krush, Anne J.

Shreffler, D. C.: vide Weitkamp, L. R.

Siegler, J.: vide Schuler, D.

Singh, S.: Inheritance of Asymmetry in Finger Ridge Counts

Skude, G. and Jakobsson, A.: Determination of Adenylate Kinase Phenotypes Employing Agar Gel 319

Solaas, Marit Hornberg: Frequency of the $\mathrm{Ag}(\mathrm{x})$ Antigen in a Norwegian

Population Sample 290

Spennati, G. F.: vide Scozzari, R.

Stafford, R. E.: Estimation of the Interaction between Heredity and

Environment for Musical Aptitude of Twins 356 
Stene, J.: Detection of Higher Recurrence Risk for Age-Dependent Chromo some Abnormalities with an Application to Trisomy Gj (Down's

Syndrome) 112

Stene, J.: A Statistical Segregation Analysis of (21q22q)-translocations . 465

Stene, J.: vide Mikkelsen, Margareta

Stern, C.: Model Estimates of the Number of Gene Pairs Involved in Pig

mentation Variability of the Negro-American

165

Stigbrand, T.: vide Beckman, L.

Subrt, I. and Hnlková, 0.: Chromosomal Abnormalities in a Girl with

Physical and Mental Maldevelopment 252

Szeinberg, A.: vide Tomashewsky, Shulamith

Tanigawa, Y.: vide Neel, J. V.

Tärnvik, A.: vide Beckman, C.

Teisberg, P.: New Variants in the C 3 System

631

Terrenato, L.; Santolamazza, C.; Scozzari, R.; Gigliani, F., and Mo

diano, G.: Red Cell Phosphoglucomutase Polymorphism. II. Den-

sitometric Studies

94

Tills, D.; Brand en, J. L. Van den; Clements, V. R., and Mourant, A.

E.: The World Distribution of Electrophoretic Variants of the

Red Cell Enzyme Adenylate Kinase (ATP: AMP Phosphotrans-

ferase) EC 2.7.4.3 517

VIII

Index

Tills, D.; Branden, J. L. Van den; Clements, V. R., and Mourant, A.

E.: The Distribution in Man of Genetic Variants of 6-Phospho-

gluconate Dehydrogenase 523

Tills, D.: vide Bonne, B.

Timson, J.: vide Hamlett, J. D.

Tomashewsky, Shulamith and Szeinberg, A.: A Rare Allele of Phospho-

glucomutase (PGMj8) in a Jewish Family of Moroccan-Turkish

Origin 638

Walker, G. F.: vide Jantz, R. L.

Walter, H.; Bajatzadeh, M., and Nemeskéri, J.: Sex and Age Relations

of Alkaline Serum Phosphatase Phenotypes 427

Walter, H.: vide Pálsson, J. 0. P.

Weitkamp, L. R.; Renwick, J. H.; Berger, J.; Shreffler, D. C; Drachmann, 0.; Wuhrmann, F.; Braend, M., and Franglen, G.: Ad

ditional Data and Summary for Albumin-Gc Linkage in Man . . 1

Wilson, R. S.: Bloodtyping and Twin Zygosity $\quad 30$

Winter, S. T.: vide Dar, $\mathrm{H}$.

Woodhead, B. G.: vide Bonne, B.

Wuhrmann, F.: vide Weitkamp, L. R.

Wyslouchowa, Barbara : Red Cell Acid Phosphatase Types in Poland.

Population and Genetic Studies

Yamamoto, M.: vide Neel, J. V.

Zhivcov, S.: vide Evrev, T.

Book Reviews 455, 566

Index rerum vol. $20 \quad 654$ 